\title{
KANBAN-RENDSZER ELLENŐRZÉSE SZIMULÁCIÓS MODELL HASZNÁLATÁVAL
}

\author{
Drahos Dorina \\ MSc hallgató, Miskolci Egyetem \\ Logisztikai Intézet \\ 3515 Miskolc, Miskolc-Egyetemváros, e-mail: ddorina.me@gmail.com
}

\begin{abstract}
Absztrakt
Egy termelövállalat legfontosabb célja a vevö minden igényének a kiszolgálása, ami akkor lehetséges, ha folyamatosan rendelkezésre áll megfelelö mennyiségü késztermék. A kanban rendszer segit a termelési rendszer folyamatos fejlesztésében, mégpedig oly módon, hogy alkalmazásával megakadályozhatjuk a túltermelést és a készlethiányt egyaránt, miközben a szükségtelen folyamatközi készleteket is csökkenthetjük. Ahhoz, hogy termelésünket a kanban rendszer használatával vezérelni tudjuk, a legapróbb részletekig ismernünk kell a gyártási folyamatainkat, hogy pontosan meg tudjuk határozni a kanban kártyák számát, melyek a rendszer alapját képezik. A kalkuláció után is érdemes szemmel tartanunk a rendszerünket, hiszen stabil müködés esetén a kártyák számának csökkentésével könnyedén fejleszthetjük azt.
\end{abstract}

Kulcsszavak: kanban, szimuláció, folyamatos fejlödés, termeléstervezés

\begin{abstract}
The most important goal of a manufacturing company is fulfilling all needs of its customers, which is only possible if an adequate quantity of finished products is available. The kanban system helps in the continuous improvement of the production system namely in a way that by its application we can prevent the overproduction and the supply shortages as well while we can reduce the unnecessary in-process stocks. In order to control our production using kanban, we need to know how it works down to the smallest detail so we can determine accurately the number of kanban cards which forms the basis of the system. Our system worth keeping an eye on even after the calculation since in case of stable operation we can easily improve it by reducing the number of cards.
\end{abstract}

Keywords: kanban, simulation, continuous improvement, production planning

\section{Bevezetés}

A kanban rendszer segít a termelési rendszer folyamatos fejlesztésében, mégpedig oly módon, hogy alkalmazásával megakadályozhatjuk a túltermelést és a készlethiányt egyaránt, miközben a szükségtelen folyamatközi készleteket is csökkenthetjük. [1]

A kanban rendszer kanban kártyák segítségével müködik, a kártyán lévő információk pontosan megmutatják, hogy miből mennyit kell gyártani vagy mozgatni. A kártya általában egy egységnyi 
termékhez tartozik, így a kanban azt jelenti, hogy ezt a mennyiséget kell átszállítani az előző folyamattól vagy ezt a mennyiséget kell legyártania a folyamatnak [2].

A rendszer akkor tud megfelelően működni, ha a gyártósor ismeretében pontosan meghatározzuk a müködtetéshez szükséges kártyák számát, ezt azonban bevezetés elött érdemes ellenőriznünk egy szimulációs modell használatával.

\section{A kanban rendszer}

A kanban rendszer egyik legnagyobb előnye, hogy húzó rendszert tesz lehetővé. Ennél a módszernél a klasszikus toló rendszerrel ellentétben a folyamat az utána következő folyamat igényeinek kielégítésére dolgozik, mint ahogy az előző folyamat is a mi húzásunkra reagál. Ez annyit jelent leegyszerüsítve, hogy a következö folyamat által elfogyasztott mennyiséget kell pótolnunk, nem pedig mindentől függetlenül folyamatos készletnövelésre törekszünk. A rendszer megfelelő müködéséhez elengedhetetlen, hogy pontosan ismerjük a folyamatot és tudjuk mekkora minimumkészletet szükséges tárolni két müvelet között, ehhez lesz majd szükséges a kanban-számítás [3].

\section{Kanban mennyiségek meghatározásának módszere}

A kanban rendszer megfelelő müködéséhez elöre meg kell határoznunk, hogy mennyi kártyára van szükségünk. Az alapelv az, hogy annyira, amennyit a következö folyamat felvesz, amíg a gyártósor pótolja az első kanbant. Például, ha a következö folyamatnak percenként van szüksége egy kanbannak megfelelö mennyiségü anyagra, a mi folyamatunk átfutási ideje pedig 3 perc, tehát 3 perc alatt tudja pótolni a kanbant, akkor 3+1 kártyára van szükség, hiszen mire a 4. egységet is leveszi, a soron elkészült egy újabb egység, így a következö levételnél nem lesz üres a tároló. Természetesen a gyakorlatban nem ilyen egyszerủ a számolás, hiszen történhetnek fennakadások [4].

A Relowisa-kalkuláció az egyik legrészletesebb számítási módszer a kanban kártyák számának meghatározásához, nevét a tényezőkből eredően kapta [5]:

$$
K=R E+L O+W I+S A
$$

ahol:

- K - kanbanok száma (Number of Kanban);

- RE - újrabeszerzési idő lefedése (Replenishment time coverage);

- LO - tételképzés miatt szükséges kártyák száma (Lot time coverage);

- WI - vevői lehívás csúcsainak lefedése (Withdrawal peak coverage);

- SA - biztonsági idő lefedése (Safety time coverage).

A kalkulációt megelőzi a folyamataink alapos, részletes feltérképezése, hiszen ismernünk kell minden mozzanatot ahhoz, hogy megfelelő számokkal tudjunk dolgozni és a végeredményünk a valóságot tükrözze. Természetesen a számokból és képletekből adódóan a kapott végeredményünk nem feltétlenül lesz egész szám, ilyenkor felfelé kell kerekíteni a kanbanok számát a biztonság kedvéért, és csak akkor csökkenteni, amikor már hosszabb ideje teljesen stabilnak találjuk a folyamatot. 


\section{Kanban rendszer vizsgálata szimulációs modell használatával}

A felmerülő problémák és kérdések megválaszolásához a szimulációs modellezés az egyik leghatékonyabb eszköz, így miután a kalkulációval megkapjuk a szükséges készletnagyságokat, érdemes ezzel a módszerrel megvizsgálnunk a tervezett rendszer müködését. A szimulációs szoftverek olyan környezetet biztosítanak a felhasználók számára, mellyel a valós rendszer modellje elkészíthető és azon bizonyos vizsgálatok végezhetők, azok eredményei kiértékelhetők.

A vizsgált rendszer szimulációs modellezésére a Plant Simulation szoftver tökéletesen alkalmas, mivel ez egy anyagáramlás szimuláció végrehajtására alkalmas rendszer. A szoftver lehetővé teszi, hogy kimutathatóak legyenek a raktározási rendszer hibái, a gyártósorok leterheltsége, valamint széles eszközkészlettel rendelkezik, amivel jelentősen könnyebb egy komplex rendszer tervezése. A Plant Simulation rendelkezik Kanban Tools könyvtárral is, így a kanban-rendszer modellezése egyszerüen megvalósítható.

\begin{tabular}{|c|c|c|c|}
\hline 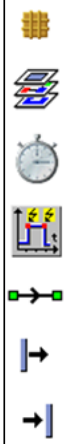 & $\begin{array}{l}\text { Entity } \\
\text { Frame } \\
\text { EventController } \\
\text { Trigger } \\
\text { Connector } \\
\text { Source } \\
\text { Drain }\end{array}$ & 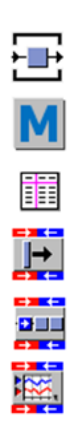 & $\begin{array}{l}\text { SingleProc } \\
\text { Method } \\
\text { TableFile } \\
\text { KanbanSource } \\
\text { KanbanBuffer } \\
\text { KanbanChart }\end{array}$ \\
\hline
\end{tabular}

1. ábra: A modellhez szükséges objektumok

- Entity (Elem): A rendszerben az anyagáramlást megvalósító dinamikus objektum, az anyagáramlás leírásának atomi egysége (mozgó eleme - MU: movable unit). Ez az egység egy munkadarabot jelképez.

- Frame (Vázlat): Ezen az objektumon tudjuk elkészíteni a modellt. Más típusú objektumok egy adott funkció megvalósításához való egységbezárására alkalmas. A Frame-k egymásba ágyazhatóak, így hierarchikus modellek készítését is lehetővé teszik.

- EventController (Eseményvezérlö): A szimuláció vizsgálati ideje, sebessége az EventController segítségével állítható be, valamint a modell inicializálása és a kezdőállapotba való visszaállítása is az ő feladata.

- Trigger (Eseményindító): A szimuláció egy vagy több előre meghatározott időpontjában a folyamat eseményeitől független eseményt generál.

- Connector (Összekötő): A modell egyéb objektumai a Connector köti össze annak érdekében, hogy a modellezett termelési-logisztikai folyamatban az anyagáramlás leképezhető legyen MU-k által.

- Source (Bemenet): A modellezés alapvető, legelső „forrás” objektuma, MU-k generálásáért felel, melyekkel az anyagáramlás intenzitását szabályozza a modellben. Megadható az MU-k pontos száma vagy sorrendje, direkt módon vagy eloszlásfüggvény szerint.

- Drain (Kimenet): Az anyagáramlási folyamatot lezáró objektum, amely eltávolítja az MU-kat a modellből és statisztikai adatokat gyüjt az anyagáramlásról. 
- SingleProc (Művelet): Az egyetlen kapacitással rendelkező objektum, amely MU fogadására alkalmas, de csak üres állapotban tud új objektumot befogadni. A gyakorlatban ez egy munkagépet jelképez, ami valamilyen megmunkálási müveletet hajt végre.

- Method (Metódus): A programozási fejlesztőkörnyezethez kapcsolódó objektum, lehetőséget biztosít arra, hogy programkódok segítségével még inkább testre tudjuk szabni a modellünk folyamatait.

- TableFile (Táblázat): Az adattárolás legáltalánosabb formája, strukturált két- vagy többdimenziós tömb. Oszlopainak típusa meghatározza a benne tárolható adatok típusát, a rekordja számos különböző típusú mezőt tartalmazhat.

- KanbanSource (Kanban forrás): Forrás jellegủ objektum, az igényeknek megfelelő egységeket lehet vele létrehozni. Fontos az objektum kezdeti felparaméterezése, azaz, hogy elöre megmondjuk milyen típusú egységeket tud létrehozni.

- KanbanBuffer: Tároló jellegű objektum, előre meghatározott típusú és mennyiségü egységet tartalmaz. A szimuláció kezdetekor ténylegesen megtörténik az egységek létrehozása a tárolóba. Az egységek kivételét vagy másik objektum, vagy metódus tudja elindítani. Ha az alkatrészek szintje eléri a minimum készletet, az objektum automatikusan rendel belőlük.

- KanbanChart: A KanbanBufferhez tartozó vizuális megjelenítő objektum, ennek segítségével diagramon is lehet követni a tároló pillanatnyi telítettségét.

\subsection{Szimulációs modell}

A modell elkészítéséhez egy fiktív gyártósort vettem alapul, ami egyféle terméket gyárt, így sok tényező nem volt szükséges a számításhoz, mivel nincs átállás. A gyártósor két gépből áll, a kettő között pedig szupermarket helyezkedik el, így két kalkulációra volt szükségem. A megadott adataim alapján a vevőhöz közelebbi Gép2 müködéséhez 6 kártyára van szükség, a Gép1-hez pedig 7 kártyára. 30 napot vizsgáltam a szimuláció során, úgy gondolom, ennyi idő elegendő ahhoz, hogy megállapítható legyen a folyamat stabilitása.

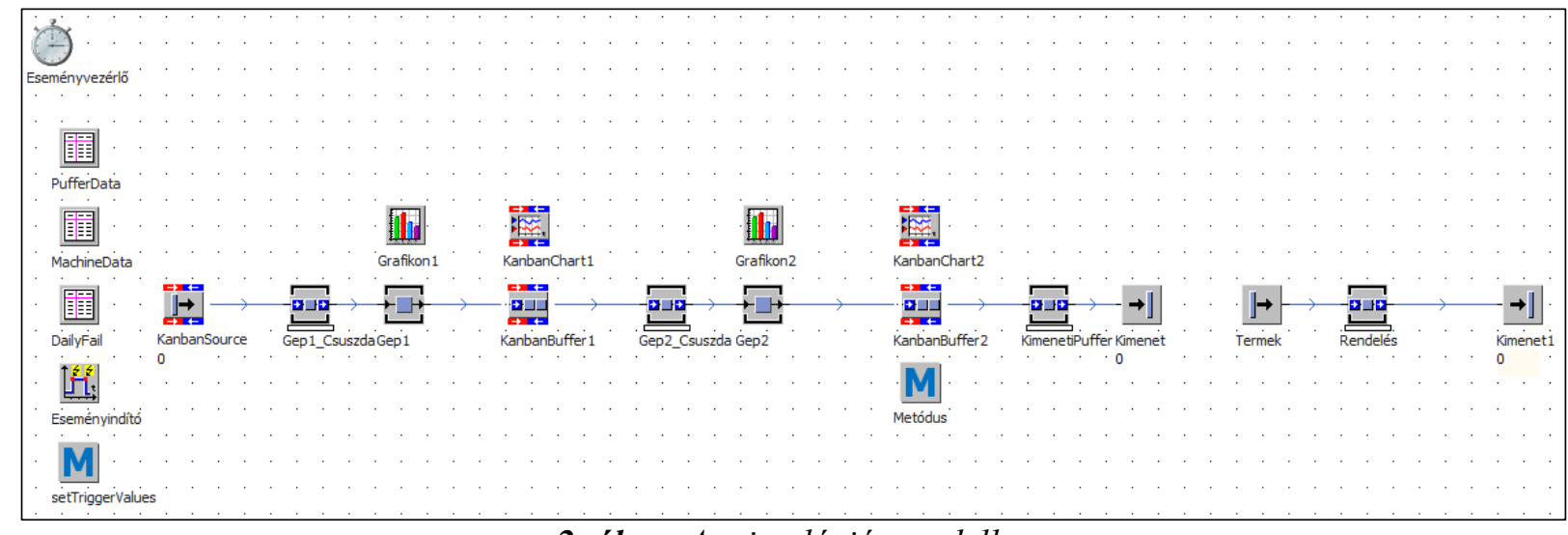

2. ábra: A szimulációs modell

A 2. ábrán látható a szimulációs modell, amelyet ehhez az egyszerü kanban rendszerhez készítettem, két gép felel az alapanyag megmunkálásáért, ezek előtt 1-1 kanban csúszdának megfelelő objektum 
található. A szimuláció kiértékelésében segítségünkre van a két KanbanChart, amik a szupermarketek készletének változásait mutatják meg a szimuláció során.

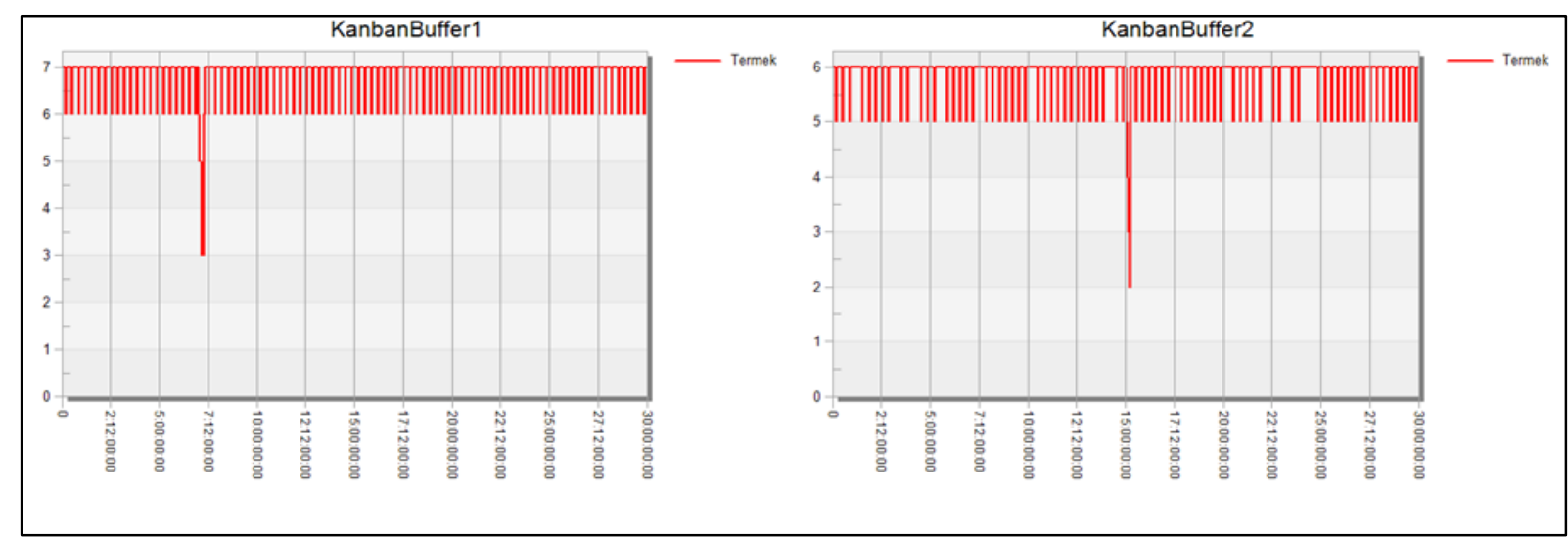

3. ábra: A kanbanok számának változása a szimuláció során a szupermarketekben 1.

A 3. ábrán látható grafikon bemutatja a két gép utáni szupermarketek készleteinek változását a 30 nap alatt. X tengelyen a szimulációs idő látható, y tengelyen pedig az aktuálisan készleten lévő kanbanok száma. A kanban rendszer teljesen stabil, az egyetlen kiugrást az általam előre betervezett 6 órás leállás jelenti, de még ekkor sem esik 2 kanban alá a szupermarket készlete. Ilyenkor érdemes megvizsgálnunk, mi történik a rendszerben, ha csökkentjük a kártyák számát.

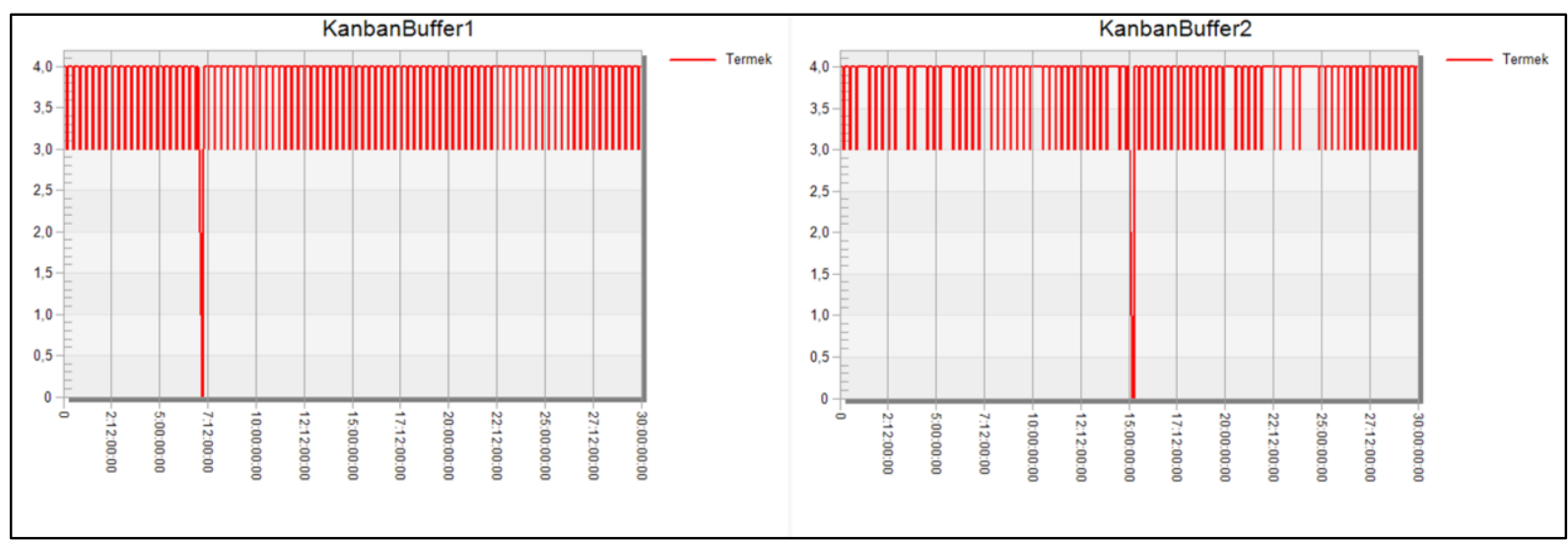

4. ábra: A kanbanok számának változása a szimuláció során a szupermarketekben 2.

A második szimulációnál mindkét folyamat kártyáinak a számát 4-re csökkentettem, ekkor már a készlet teljesen kiürülne egy 6 órás leállás során, de a vevőt még ki tudnánk szolgálni, mert a gyártás újraindul mire újra szüksége lesz a termékre. Ha tovább csökkenteném a kártyák számát, akkor már valószínűleg nem tudnánk időben rendelkezésre bocsájtani a készterméket a vevő részére, ami szembe menne a vállalat legfőbb céljaival.

Bár a második szimuláció is eredményesen futott le, a valóságban egy 6 órás leállásnál nagyobb problémákkal is találkozhatunk, illetve elöre nem várható hibák is okozhatják a gyártósor hosszabb 
leállását. A kalkuláció során természetesen ezeket a paramétereket is figyelembe vesszük, ezért úgy gondolom, hogy érdemes elöször mindenképpen a kalkulációval meghatározott mennyiségü kártyával bevezetni a rendszert, hiszen egy új rendszer esetén a dolgozóknak is alkalmazkodniuk kell az új megoldásokhoz, ezek eleinte több időt vehetnek igénybe. Később pedig bármikor fejleszthetünk a folyamatokon, ha úgy látjuk, van erre lehetöségünk.

\section{5. Összegzés}

A kanban rendszer bevezetésénék számos előnye lehet egy termelővállalat életében, így mindenképp érdemes megfontolni használatát, ha van rá lehetőségünk. Bár elsőre riasztó lehet az ezzel járó munka mennyisége, de a stabil rendszer gördülékenyen és sokkal hatékonyabban müködik, mint egy termelési tervvel irányított gyártás és a tervezési idő is jelentősen csökken általa. A rendszer bevezetésének egyik legfontosabb lépése a folyamataink alapos feltérképezése, hogy minél pontosabb kalkulációt tudjunk elkészíteni és egy stabil rendszert hozhassunk létre, hiszen ez az elsődleges cél. A bevezetés előtt hasznos lehet szimulációs modell segítségével ellenőriznünk a rendszer stabilitását, ha ezt megfelelőnek találjuk, akkor jöhet a fizikai megvalósítás.

\section{Köszönetnyilvánítás}

A cikkben ismertetett kutató munka az EFOP-3.6.1-16-2016-00011 jelü „Fiatalodó és Megújuló Egyetem - Innovatív Tudásváros - a Miskolci Egyetem intelligens szakosodást szolgáló intézményi fejlesztése" projekt részeként - a Széchenyi 2020 keretében - az Európai Unió támogatásával, az Európai Szociális Alap társfinanszírozásával valósul meg.

\section{Felhasznált irodalom}

[1] Drahos Dorina: Kanban-rendszer tervezése Relowisa-kalkuláció használatával, Multidiszciplináris Tudományok - Fiatal Kutatók különszám 2020, 10(2):183-192. https://doi.org/10.35925/j.multi.2020.2.23

[2] Kosztolányi J., Schwahofer G.: Zsebedben a Lean sorozat, Kaizen Pro Kft., 2012.

[3] Kosztolányi J., Schwahofer G.: Útmutató a lean gyakorlati alkalmazásához, Kaizen Pro Kft., 2016.

[4] The Productivity Press Development Team: Kanban a gyakorlatban, Budapest, Kvalikon Kft., 2011.

[5] Pedro Salgado, Leonilde Varela: Kanban sharing and optimization in Bosch Production System, Braga, Portugal. https://www.academia.edu/ 